\title{
LESSON 39
}

MARGINS: Pica, 20-70; Elite, Type this sentence as many times as your teacher asks.

30-80.

Warm up

Clinic

Revise a key

Keep the fds fingers in position as you type a.

Revise b key

Keep the asd fingers in position as you type $b$ with the $f$ finger.

Increase Speed

25 wpm 2 minutes.

S16-SI 1.08

S17-SI 1.16

Improve Accuracy

20 wpm 2 minutes.

A13-SI 1.27

A14-SI 1.47

Test your Skill

5 minutes.

T6 - SI 1.09

Use double-line spacing.

Mark all faults and look up the Clinic Index for the corrective exercises.

Try the test again.
1. The flight was quite an experience but it was over much too quickly for Paddy, Jim and Zoe.

Type each line 3 times paying attention to good technique.

2. a at an ant and add arc are after apple alone able

3. ran was tank make name rain cave range paint raven

4. Alexis was alone and all along that lane was dark.

5 . be by but bat bus bin ban both boat beer babe bang

6. ebb able tube fable tribe bomb rabbit bible marble

7. Bill Brown bought both blue books by Barbara Bond.

As the fire would not start because the paper was much too wet he had to hunt in the hedge banks and find some dry twigs and dead leaves to help it to catch light. The cold wind blew harder, and he could not see in the fading light. Help must come soon.

Both teams had trained hard to make the final and the large crowd added to the tension felt by a large number of the players. The match was spoilt by the first half in which there were far too many fouls and it was not until the second half that it improved.

Until recent times the tomato was not grown a great deal. People did not eat the fruits because they thought them unsafe. In modern times we know them as a valuable salad crop and most people like them.

The carnival ended at last and taxis streamed into the brightly lit loading area where exhausted but happy revellers tumbled into them before being driven home. It had been such a fine warm day for them.

One of the better ways to spend an evening is to have a meal and a bottle of wine with your best friends. Many wines are quite cheap and you could soon learn how to tell a good one from a poor one. White wines are drunk with fish or poultry while a red wine is drunk with red meat. White wines seem better if they are slightly chilled while red wine is at its best when served at room heat. The main thing is not to pour either too hot or too cold, a fault that is all too common. Wines are made from grapes.

\begin{tabular}{|l|l|l|l|l|l|l|l|l|l|l|l|} 
& 1 & 2 & 3 & 4 & 5 & 6 & 7 & 8 & 9 & 10
\end{tabular}

UNIT 10/CONSOLIDATION LESSON 39 